\title{
From Hell to Heaven: The Children of God Dance Rimbaud's Development of Baudelaire's View of Poetry
}

\author{
Xiao-Bo Zhang ${ }^{1, *}$ \\ ${ }^{1}$ Major in Chinese Language \& Literature, School of Literature and Journalism, Xiangtan University, 411100, \\ Xiangtan, P.R.China. \\ *Email:3221411649@qq.com
}

\begin{abstract}
Both Rimbaud and Baudelaire are famous symbolist poets among the representatives of French poets and have made a significant impact on the field of poetry later on, even among which Rimbaud has created many immortal poems in his short time of poetry. In this paper, by comparing Baudelaire's poems with some typical poems of Rimbaud, it will analyze the same spirit of resistance and struggle between the two poets in the context of their times, and the idea of psychicism put forward by Rimbaud is precisely the inheritance and development of Baudelaire's binary aesthetic view of poetry.
\end{abstract}

\section{Keywords: Symbolism, The French Poetry, Rimbaud, Baudelaire}

\section{INTRODUCTION}

In terms of poetic theory, Rimbaud inherited Baudelaire's mantle and further promoted the development of the aesthetic theory of symbolism. Rimbaud said this about him: "Baudelaire was the first psychic, the king of poets, a true god. But he had lived in too much artistry, and the forms for which he is so celebrated were banal: unknowable inventions demanded new forms!" Although both of them were early Symbolist poets, their styles were very different. Baudelaire was a man who lived in the city and witnessed countless ugliness, squalor and misery. He struggled in his poetry, numbed himself with opium and alcohol, and blossomed out of the dust with the flower of evil. Rimbaud, on the other hand, is much hotter and purer, and his poems are like children splashing ink with the fragrance of wine ${ }^{[1]}$.

\section{ANALYSIS OF THE MAIN POETIC STYLES OF THE TWO POETS}

In the history of Western literature, the political and economic complexity of the late 19th century, many philosophical thinking is flowing and various literary schools are appearing, the most important of which are naturalism, aestheticism and symbolism. Baudelaire was the pioneer of the Symbolists. He wrote a lot about the ugliness in the city, advocated turning ugliness into beauty, seeing beauty in ugliness, reflecting abstract facts with concrete imagery, and using various generic and symbolic techniques. These are the characteristics of symbolist literature. Therefore, he became a pioneer of symbolism.

Modernism is not a mere literary genre. It is the collective name of many literary schools in the 20th century, which is to distinguish them from the various literary schools before the 20th century, such as Futurism, Expressionism, Stream of Consciousness, and so on. However, all these schools have some common characteristics: the most important characteristic is that they are anti-traditional, abandoning the whole traditional civilization, thinking that all the classical civilization is outdated, worthless or inhumane, and should be abandoned ${ }^{[2]}$. Therefore, in art, many schools of modernism generally use the literary mode of symbolic metaphor, depicting a lot of ugly things, advocating ugliness as beauty, trying to find beauty in the exposure of ugliness, sublimating beauty (is there any more familiar), etc. Hence, modernism has a common characteristic: the most important characteristic is to abandon the whole traditional civilization. Thinking that classical civilization is all 
outdated or inhuman should be discarded. So, it can be said that the modernists inherited Baudelaire's aesthetic concepts directly in the inner spiritual core. Baudelaire's poetic creations and theories directly influenced the second half of the 19th century (Symbolists) and the 20th century European and American literature (Modernists) $^{[3]}$. He is the pioneer of Symbolism and the originator of Modernism.

Symbolism holds that the world consists of two levels: the material world, which is impermanent, and the ontological world, which is constant and unchanging. The latter consists of the idea behind matter and is the layer closer to the essence. Baudelaire, as the founder of symbolism, put forward many famous poetic views. He advocated the expression of the inner "highest reality", which is often composed of the poet's mysterious feelings and dreamy moments, full of vague ideas and subtle emotions. The imagery is piled on top of each other in a way that is subtle but often difficult for future generations to understand.

\section{THE SAME REBELLION AND STRUGGLE}

Baudelaire's family was not very harmony. Even he was determined to become a writer, he maintained a decadent and profligate life, a typical prodigal son. After depleting his father's inheritance, his life was in dire straits, and the meager fees from his reviews and poems could hardly sustain him. Long-term worries, debts, etc. made his body unusually weak, and he finally died of neurological disorder.

The more than 100 poems of the Flower of Evil are divided by Baudelaire into six sections according to their content, writing about the poet's spiritual exploration. The first section is "Melancholy and the Ideal," in which melancholy eventually triumphs over the ideal, setting the emotional tone for the entire collection. Followed by "Scenes from Paris," it describes the various unsightly urban scenes of Paris, showing a dirty and filthy big city. Then comes "Wine," about self-submersion and the use of alcohol to anesthetize oneself. It followed by " Les Fleurs Du Mal," in which the poet turns from the illusion of drunken dreams to confront sin, which gradually grows in the repression of the soul. Then comes "Rebellion," a rebellion against God, praise of Cain and Satan, and finally "Death ${ }^{[4]}$.

Baudelaire, as a prodigal rich boy, has a good foundation of knowledge about the true, good and beautiful, and possesses a powerful language ability. But after repeatedly experiencing the pleasure of true beauty, he realized what reality is like. The pain of this fragmented aesthetic and the emptiness of true beauty day in and day out began to torment him. So, he turned to a deeper essence, no longer just looking at the true beauty, but capturing every detail that can move people. No matter if it is joy, sorrow, sadness or joy, he just keeps trying to be as crazy as possible, to make that kind of moving pure. This is why many reviews mentioned Baudelaire like thunder like a sharp sword. This kind of Baudelaire actually brings a new attitude, an incomparably broad attitude that can accept everything, and with his brush that can wander on the most delicate nerves, a part of his works is born.

As long as education can produce a large number of people who believe in truth, goodness and beauty, but whose beliefs are shaky when they are examined, the flower of evil can be the key to open the door to a new world.

Born in 1954 in Charleville in northeastern France, Rimbaud has the same spirit of rebellion and struggle. His father's departure at the age of six and his mother's withdrawn nature made his early family atmosphere very depressing and created a rebellious and restless soul. While still in high school, he showed his natural talent. Under the guidance of his teachers, he became increasingly proficient at writing poetry in French. At the age of sixteen, Rimbaud wandered and met Weiland, a symbolist poet ten years older than him, and fell in love with him. The years of his love affair with Verlaine were also the period when Rimbaud concentrated most on his poetry. It can be said that his appearance as a poet in the French poetry scene lasted less than five years. As brilliant and fleeting as a firework, his contribution to French poetry is remarkable and immortal. Rimbaud's enigmatic poems and legendary life set a paradigm of survival and rebellion for the world to come, and Rimbaud's masterpiece, deserves to be read by all of us.

As a "psychic", Rimbaud is at odds with the present world. He is a stranger on the earth. He opposes religion and places himself above good and evil; he opposes Western civilization and holds the highest respect for the mysteries of the East; he opposes labor and the process of modernization, and the city is a rotten pond of misery for him, a mire of uniformity that traps the spirit and flesh of countless people. He dreamed of a pure land away from the hustle and bustle of the world.

In Rimbaud's eyes, the lined-up buildings make people lost in them, the uniqueness of individuality is replaced by the standardized production process, the joy and meaning of life is dissolved, and eventually people become ghosts, only "rolling through the thick and eternal soot" ${ }^{[5]}$. He calls for a flood, longing to erase the sins of mankind: Western culture, religion, the products of modernization - hoping to sweep away the filthy mud of the earth. As a pioneer of his time, he was tormented in his heart, but did not sink. He took upon himself the burden of aesthetic enlightenment, and wrote about the reversal of good and evil, the overthrow of religion, and 
the fall of civilization. By recreating the spirit of dead things, he made a strong resistance to the times with his rebellious words.

Rimbaud is more like a kind of inspiration and enthusiasm, with his imagination gushing out, writing about Le bateau ivre when he had not yet seen the sea. Rimbaud should be a gifted poet, as if he was born with the talent. Some people say that even if Rimbaud takes off his halo, away from the lies of reputation and art, he is still the same Rimbaud. He lived in the kingdom of poetry he had constructed, ignoring the world, just writing poems with a single-minded focus, with his food and lodging mainly provided by Weiland, he just didn't care about the world, and by nature he yearned for those things of immense beauty.

Baudelaire's poems blossomed in the dust. $\mathrm{He}$ witnessed all the sins and remorse in the earthly world, so he suffered, he was blinded, he struggled in his poems, yet always in the mire of the human world, "once fallen into the earthly world of laughing and cursing by people, the mighty and powerful feathers are not able to move an inch."

\section{PSYCHIC THOUGHT: THE INHERITANCE AND DEVELOPMENT OF BAUDELAIRE'S POETIC BINARY AESTHETIC VIEW}

The Les Fleurs Du Mal has completely become a symbol of Baudelaire. When one thinks of Baudelaire, the first thing that comes to mind is Les Fleurs Du Mal, and it is impossible to separate the two. It is impossible to distinguish whether it is Baudelaire's Les Fleurs $D u$ Mal or Baudelaire's Flowers of Evil. Before and after him, the critical controversy surrounding him has been so loud that he has left almost as much fame as stigma in the history of world literature. Victor Hugo said it "shines like a multitude of stars", Alfred de Vigny saw it as "the flower of goodness", Edmond Cheret only smelled the "stench" that made the readers cover their noses. As for the poet, Rimbaud calls him "the true God", T.S. Eliot calls him "the highest model of poets in all modern countries", Ferdinand Brunagier calls him "the Satan of hotels"[6]. One wonders whether these literary figures are talking about the same book. But this is precisely where Baudelaire's value lies. Leaving aside the solitary and melancholy side of his character, the contradictory assessment of him reflects his two different roles - the deconstruction of mainstream values and the establishment of the symbolist literary paradigm.

Baudelaire's creative advocacy of ugliness as beauty greatly enhanced the expressive power of literature to depict ugliness and evil, which sparked a trend in the 20 th century. His theory of empathy provided a mystical view of the world, arguing that there is a mystical spiritual reality behind the world, that the poet is the psychic who conveys this reality, and that a variety of different feelings can be empathized with, and that the method of expressing the empathy is symbolism. Baudelaire's innovation in poetry is evident to all; he promoted the emerging prose poetry and also proposed to use poetry to find modernity.

The aesthetics of dichotomy is reflected in Baudelaire's poetry. Baudelaire discovered the secret of beauty, not in that assiduousness, not in that leisurely serenity, not in that classical elegance. Beauty is in the reality, in the educated, interesting but hypocritical chat, in the glamorous but obscene flesh, in the noisy and lively but empty banquet. Beauty is the ugly essence under all the gorgeous appearance - beauty is ugly!

From " Le bateau ivre" to " Les Illuminations", Rimbaud's poetic talent is not only reflected in his creative work, but also in his unique view of poetry the aesthetic concept of "psychic". Baudelaire was the first psychic to be recognized by Rimbaud. He pointed out in his Essay on Harmony that there is a relationship of mutual harmony between the various human senses (later called "psychic"). Rimbaud also pondered what beauty is, and inherited Baudelaire's ideas of psychic inspiration, becoming a true psychic. The illusion is rooted in the soil of the present world, but grows out of exotic vines. Rimbaud lived in an era when the rapid development of industry drove the material expansion of society and plunged the human spirit into an irrational crisis. As religion became more and more involved in the mundane world, the magnificent curtain was torn away, the golden body fell from the altar, and the sacred light gradually dissipated. Faith is lost, and the individual is plunged into nothingness. Poetry is the most sensitive, which changed first.

Poetry for Rimbaud is an invocation - not an artistic pursuit, but a spiritual activity itself. By pouring out the original language, he leads the reader into a world of illusion that lies between reality and unreality. There, the poetic dazzle is fixed and everything is clothed in strange and bright colors--Rimbaud's words are so crisp and sharp that the essence of the world is split down the middle and exposed to the outside world without reservation. Like a sharp blade with silvery light, it is so straightforward that it is even a bit brutal. Rimbaud's verses, with their vigorous vitality, inject the pleasure and vitality of the real world beyond the mundane. He writes, "The lights and carpets of the long night send out waves of noise, night, along the hull of the ship, around the unified cabin." The dancing lights and carpets in the house give the poet the feeling of being in the cabin of a ship sailing at night. The darkness of the night is transformed into a solid, "along the hull of the ship", which surrounds the person, rendering the atmosphere of solitude. The poet is awake alone in this long night, gazing longingly at the things in the house, 
and the tapestry is transformed into a dentate grove. "Emerald in color, the turtles of the night swoop there" is quite psychedelic. The poet starts from the material object on the surface and gradually dives down to the depths in order to reach the world of illusion.

For Rimbaud, "the various senses must be made to experience a long, extensive, conscious dislocation, various forms of love, pain and madness, before the poet can become a psychic." He activates things by completely disrupting the senses, using words that "derail" them in order to get as close as possible to their essence, to reach the other side of the unknowable. "This language will reach from the soul to the soul, outlining everything, aromas, sounds, colors, thoughts interconnecting with thoughts and leading to thoughts." Rimbaud does indeed do this. Reading his poems, the inner experience stumbles as well. The verses are short, but contain a richness of imagery and sensation. For example, Rimbaud writes, "As public funds are lost at the fraternity celebration, the clouds ring with the bell of rosy flames. The palette is tipped over and the sound is tinted with color. The blank darkness of the night is polished into powder and falls lightly. The poet gives weight to the emptiness, making it palpable. In this way, different senses merge into one, communicating and interlocking with each other, moving and transforming each other. The opening of the senses brings a refreshing feeling to people, allowing them to reexamine ordinary things with the sensitive and novel perspective of a newborn child.

The freshness of language comes from his pure heart. According to his own words, "As a child, certain skies refined my eyesight". A strange childhood experience shaped the keen artistic insight of young Rimbaud. He invented the alchemy of words, "using the rhythm of instinct and a whole language of poetry," a language that could appeal directly to the consciousness of the senses. He depicts silence, paints the night, fixes vertigo and preserves texture. He resorts to the most naked and fiery inner struggles, contradictions and pains on paper and pen, and dedicates all of himself to poetry - his words are a gift of beauty. It is also those broken phrases, unfinished movements and fractured lines that break the original rigid paradigm of poetry, creating a chaotic yet unified power, dangerous yet fascinating.

\section{CONCLUSION}

The influence of Baudelaire on Rimbaud's view of poetry was tremendous. During Rimbaud's short creative time, Rimbaud produced a large number of Symbolist poems, all of which were deconstructors of the mainstream values of the times they lived in. The two have similar experiences, leading them to become "psychic poets". Both of them had similar experiences, which led them to be dissatisfied with the society at that time, and they kept writing to voice out their , full of resistance spirit. However, the difference is that Rimbaud still has a small happiness in love, and has more innocence than Baudelaire.

\section{REFERENCES}

[1]Yiting Yuan. Psychic Boat: Imagery Analysis of Rimbaud's Drunken Boat [J].Masterpieces Review.2021,(24):82-83.

[2]Yiting Yuan. The Fire stealer, the Alchemist and the Psychic--On Rimbaud's Theory of Poetry. Masterpieces Review. 2021, (18):84-85.

[3]Ni Zhang. The Modernity of Rimbaud's Poetics from the Perspective of Artistic Integration[J]. Popular Literature and Art. 2021, (05):13-14.

[4]Shuyu Wang. The Paradox of Baudelaire's Aesthetic Modernity[J]. Aesthetics. 2021, (11):17-19.

[5]Weixiang Xu. The Baudelairean Evil: Moral or Aesthetic [J]. Journal of Tongji University (Social Science Section). 2021,32(05):104-113.

[6]Jinyun Zhong. The "Evil" in Baudelaire's Aesthetic Thought: In Honor of the 200th Anniversary of Baudelaire's Birth[J]. Etudes Francophones.2021, (04):72-81+92-93. 